МИКОЛА ЧУМАК, доктор педагогічних наук, завідувач кафедри теорії та методики навчання фізики та астрономії, Національний педагогічний університет імені М. П. Драгоманова, Україна ORCID ID 0000-0002-9956-9429 chumak.m.e@gmail.com

\title{
ПРОСВІТНИЦЬКІ ПОЧИНИ ПЕДАГОГІЧНОЇ ЕЛІТИ В УМОВАХ ЕМІГРАЦІЙНИХ ТАБОРІВ (20-ті рокИ ХХ столітТя)
}

\author{
MYKOLA CHUMAK, Doctor of Pedagogic Sciences, Head of the \\ Department of Theories and Methods of Teaching Physics and \\ Astronomy, National Pedagogical Dragomanov University,Ukraine

\section{THE EDUCATIONAL BEGINNINGS OF THE PEDAGOGICAL ELITE IN THE CONDITIONS OF EMIGRATION CAMPS (20-ies of the $\mathrm{XX}$ century)}

У статті аналізується проблема розвитку освіти в системі еміграційних таборів. Підкреслено, що значущість у розвитку вітчизняної освіти в еміграційних умовах відіграли сумарні зусилля українських емігрантів, актуалізовані більшою мірою політикоцентрованою першопричинністю.

Зазначено, що регіональне укорінення радянської влади та придушення української революції боляче вдарило по соціокультурному розвитку України. Зауважено, що проблематичність вітчизняної життєдіяльності позначилася на: незавершеному будівництві національної школи; перерваній українізації; посиленні заполітизованої ідеологізації на всіх рівнях ступеневої системи освіти.

Охарактеризовано, як в умовах військової та політичної нестабільності закордонне облаштування внутрішньоемігрантського життя окремішніх українців відбувалося за просвітницької підтримки свідомої інтелігенції, котра дещо пом'якшувала "різкоконтинентальний" клімат приймаючої сторони.

Аргументовано, що розвиток освіти в еміграційних умовах проходив 3 урахуванням інтересів різновікових груп вихованців. 3'ясовано, що енергійні представ-

(C) М. Чумак ники проукраїнського професорсько-викладацького складу узяли на свої плечі тягар розвитку освіти різних освітньо-кваліфікаційних рівнів, оскільки показник вітчизняних вихованців за кордоном того часу був досить високим. Виокремлено, що такий підхід до справи достатньо виправданий, оскільки українська молодь у чужоземних умовах потребувала кваліфікованої підтримки з метою "відкриття" нових горизонтів подальшого працевлаштування. Зауважено, що в умовах складного i швидкоплинного часу у вітчизняного професорсько-викладацького складу не залишалося часу на роздуми щодо варіативності розробки змістового матеріалу навчальних дисциплін, оскільки формування лекційних конспектів українознавчої центрованості потребувало досить гнучкої оперативності.

Підкреслено, що загальноосвітня діяльність у таборах (зокрема, підготовка у формі курсів підготовчих і загальної грамотності) не була спонтанною, а нагадувала високоорганізований i досить продуктивний навчальновиховний процес. Підсумовано, що змістова наповненість робочого навчального плану залишилась досить варіативною.

Ключові слова: еміграція, професорсько-викладацький склад, університет, соціокультур- ний розвиток.

Summary. The article analyzes the problem of development of education in the conditions of emigration. It is emphasized that the overwhelming significance of the development of education with the total efforts of Ukrainian emigrants was actualized to a greater extent by its own policy-centred primary cause.

It is noted that the regional entrenchment of Soviet power and the suppression of the Ukrainian revolution hurt the socio-cultural development of the country, simultaneously affecting: the unfinished construction of a national school; interrupted Ukrainization; intensified the politicized ideologization at all levels of a graduate education system. In the conditions of military and political instability, the arrangement of the domestic-emigrant life of Ukrainians took place under the conditions of the camp system. Certainly, this system was rather depressing for the newly arrived Ukrainian, but, through the efforts of educational initiatives of the conscious intelligentsia, it was possible to somewhat mitigate the "sharply continental" climate of the host party.

It is argued that the development of education in emigration conditions took place taking into account the interests of 
different-year-old pupils. Taking into account the fact that the number of young people without higher education in the conditions of emigration was quite significant (in particular, in Czechoslovakia, the percentage of potential applicants exceeded 95\%), energetic representatives of the proUkrainian faculty took on their shoulders the burden of developing the education of various educational-qualification levels. It should be noted that such an approach to the case was sufficiently justified, since Ukrainian youth in foreign conditions needed qualified support to "open" new horizons for their further employment. In a difficult and fast-moving time, the domestic faculty did not have the time to reflect on the variability of the content development of academic disciplines, since the formation of lecture notes on Ukrainiancenteredness required a fairly flexible operational level.

It was emphasized that general education activities in the camps (in particular, preparation in the form of courses - preparatory and general literacy) were not spontaneous, but reminiscent of a highly organized and highly productive educational process. Such generalization was made due to the content diversity of the working curriculum, which provided for the teaching of disciplines in the humanities, natural sciences, physics and mathematics

Key words: emigration, teaching staff, university, sociocultural development.

Мета: проаналізувати продуктивність просвітницьких починів педагогічної еліти під впливом мінливості історичних реалій першого двадцятиріччя XX століття.

Постановка проблеми в загальному вигляді. Реконструкція освітньої стратегії у напрямі формування найбільш ефективного механізму реалізації основних завдань навчання, виховання i розвитку вимагає по-новому переосмислити вплив історико-педагогічної минувшини на академічні реалії сьогодення. Актуальність дослідження обумовлена необхідністю переосмислення знакових сторінок вітчизняної історії, які віддзеркалюють усю глибину наявного педагогічного досвіду наших співвітчизників. Особливо цінними є наявні розвідки, у яких розкривається проблема реалізації педагогічних функцій в умовах еміграції, що дозволяє повною мірою відтворити продуктивність діяльності вітчизняної еліти на іноземних теренах.

Аналіз досліджень і публікацій. Певну наукову дотичність до обраної проблематики дослідження знаходимо на сторінках авторських праць В. Андрущенка, Н. Дем'яненко, О. Лавріненка, В. Сиротюка, Т. Завгородньої, Т. Дудки та інших. Проте окреслення виучуваної проблеми епох нині потребує все глибшого авторського відрефлексування, що детерміноване необхідністю реалізації на загальнодержавному рівні стратегій відбудови національної школи.

Зосередження авторської уваги на заявленій тематиці дослідження продукувало виокремлення ряду дослідницьких завдань:

- проаналізувати рівень вивченості проблеми в розрізі джерелознавчої бази;

- актуалізувати вплив прогресивної педагогічної спільноти на підвищення рівня освіченості в умовах еміграційних таборів;

- популяризувати наявний історико-педагогічний досвід розбудови вітчизняної школи в сучасних соціокультурних умовах.

Виклад основного матеріалу дослідження. Прихід на вітчизняні терени Першої світової війни став справжньою кармою для українського суспільства та освітньої сфери зокрема. Незрозумілим чином реверанси долі черговий раз боляче вдаряли по тих сферах соціокультурного розвитку, відбудова яких була найбільш складною для усього українського соціуму. Історичний розвиток українських земель не виднів на широкий загал "лавровим листям", а навпаки, нагадував колючий терен імперських заборон, утисків та шовінізму, який боляче впинався у зболіле тіло нашого народу. Кровопролитним шляхом українство боролося 3 несправедливістю та жорстокістю лютого ворога i, що найцікавіше, на власних землях.
Вражі сили намагалися посіяти зерно масової неграмотності, оскільки боротися зі свідомою інтелігенцією було досить складно та виснажливо. Політика ворожих сил змінювала напрями освітніх курсів таким чином, що припливи ліберальних реформ поступово відступали $з$ приходом нових, більш різких - консервативних. У цілих поколінь українців поступово вироблявся так званий "імунітет" на ворожу експансію, яка все посилювала зовнішній тиск на молоде і недостатньо свідомо зріле покоління. Попередні покоління відрізнялися від сучасних дедалі більшою пристосованістю перших до "екстремального" життя у так званому "червоному" таборі, який так спритно облаштовувала радянська влада, сіючи отруту чвар між представниками різних соціальних інститутів.

3 такими жертовними умовами існування на рідній землі погоджувалася вітчизняна інтелігенція. Це була не втеча від наявної соціокультурної реальності, а передусім важлива історична місія - зберегти в умовах більш сприятливого клімату близького і далекого зарубіжжя хоча б невеликий інтелігентний паросток, 3 якого згодом проросла б нова генерація, необхідна для утвердження самостійної Української держава. Часи імперсько-радянських лихоліть не зламали життєздатного кореня української нації, просоченого життєздатними краплями народного оптимізму подвижників українського слова за славетною істиною "...поховайте та вставайте..." (Семчишин, 1993, с. 174).

Такий швидкоплинний перебіг вітчизняної історії, коли наше студентство поступовими кроками все ж наблизилося до відкриття проукраїнських університетів на території Київщини та Галичини, проте змушене було переорієнтуватися на визвольний шлях боротьби, зокрема, забарвлений кровопролитними подіями під Крутами (1918 р.).

Епохальність хвиль української еміграції на поч. ХХ ст. видніла трьома часовими відрізками:

- перший - приурочувався до небажання галичан і буковинців увійти в ярмо "червоного" табоpy; 
- другий - пов'язувався 3 лінією наступу Першої світової війни;

- третій - обумовлювався революційною поразкою проукраїнських національно-демократичних сил (Баран, 1995, с. 571577).

Кожна 3 перелічених вище хвиль відрізнялася ключовою першопричинністю, яка актуалізувала ㄲï появу на порядку денному. Так, першу можемо вважати загрозою, другу - військовоцентрованою, а третю - політикоцентрованою. Помітним ефектом виділялися й побіжні причини, які певною мірою підсилювали сумарну дію зазначеного тріо.

У розрізі саме даного дослідження нам видається доцільним підкреслити основоположну значущість того, що розвиток освіти сукупними зусиллями українських емігрантів був актуалізований більшою мірою власне політикоцентрованою першопричинністю. Авторська позиція грунтується на аналізі наявних історіографічних джерел епохи, які беззаперечно підтверджують правдивість викладеного твердження (Баран, 1995, с. 13).

Регіональне вкорінення радянської влади та придушення української революції боляче вдарило по соціокультурному розвит- ку країни, паралельно позначившись на:

а) незавершеному будівництві національної школи;

б) перерваній українізації;

в) посиленні заполітизованої ідеологізації на всіх рівнях ступеневої системи освіти.

Історіографічні джерела засвідчують, що після територіального утвердження в Україні більшовизму чисельність емігрантів-освітян зросла "...у помітному обсязі..." (Украӥнське еміграційне.., 1922, с. 18). Тим не менше, українці прагнули "...правди, крадучись нишком через кордони та оминаючи... вартових..." (Фельитинский, 1991, с. 73).

В умовах військової та політичної нестабільності облаштування внутрішньоемігрантського життя українців відбувалося в умовах табірної системи. Безумовно, що ця система була досить гнітючою для новоприбулого українства, проте зусиллями просвітницьких ініціатив свідомої інтелігенції вдавалося дещо пом'якшити "різко континентальний" клімат приймаючої сторони.

3 метою унаочнення соціокультурної значущості впливу педагогічних ініціатив на реалізацію просвітницьких функцій інтелігентними колами українства в умовах окремих еміграційних та- борів розроблено відповідні наочні матеріали (див. таблиц̧ю) (Леник, 1990; Інструкиія для...; Терлецький, 1995; Світ правди.., 2006).

Унаочнення окремого джерелознавчого фактажу дозволило виокремити багатоаспектність просвітницької діяльності українських педагогів у жорстких еміграційних умовах діючих таборів. Зокрема, український просвітникфілолог, який тривалий час працював на педагогічній ниві еміграційного табору Роштадт (Німеччина) В. Сімович, видав досить цінний навчальний матеріал "Практична граматика української мови" (1918р.) (Ковалів, 1953).

В історіографічному дослідженні "До історії нашої зачиненості" автор підкреслює, що повноцінне утвердження позицій радянської влади на вітчизняних теренах призвело до того, що вже у 1928 р. настав період тотальної заборони еміграційних виїздів (Фельитинский, 1991). Недарма тоталітаризм Сталіна історіографічні джерела "охрестили" лещатами, оскільки форсованість низки трагічних подій та дискримінаційних заходів цього періоду була неминучою для тієї частини населення, яке вже не мало змоги покинути прорадянську територію України (Білас, 1994).

Таблиияя

Соціокультурна значущість в пливу педагогічних починів на реалізацію просвітницьких функцій інтелігентними колами украӥнств а в умовах окремих еміграційних таборів (Леник, 1990; Інструкція для...; Терлецький, 1995; Світ правди.., 2006)

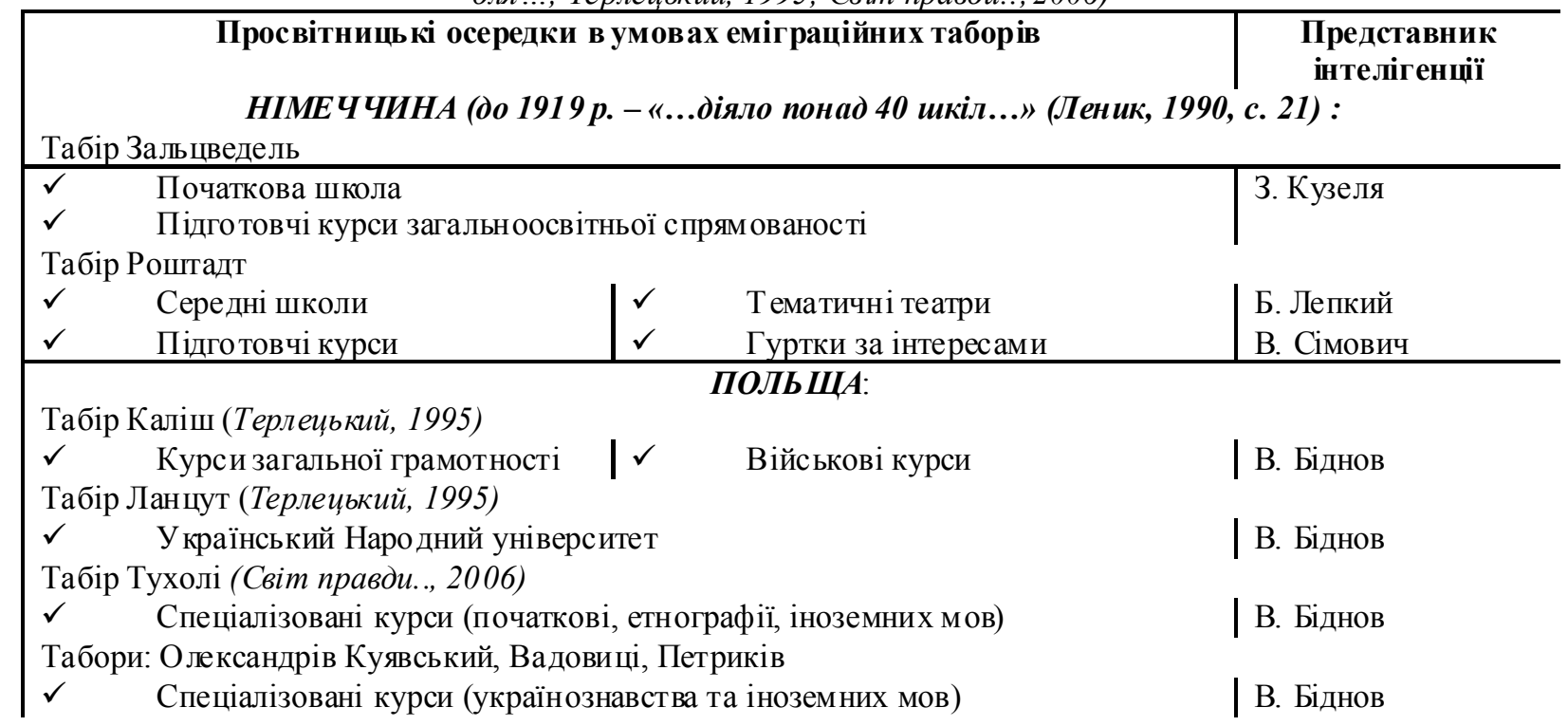


Швидкоплинні українські інтелігентні кола, чисельність котрих за окремими статистичними показниками сягала близько $1 / 3$ від загальної кількості всіх емігрантів, розпочинали життя, так би мовити, 3 чистого аркуша, оскільки жодна 3 країн, куди прибули наші співвітчизники, не була готовою до прийому такої значної кількості іноземного контингенту (Баран, 1995; Українське еміграчійне.., 1922).

У найбільш виграшній ситуації від наявної історичної подієвості опинилася приймаюча сторона, оскільки її кордони перетнув "цвіт" українського суспільства. Хоча і у цьому ключі виявлялися певні історичні нюанси. Справа в тому, що керівництво тих європейських країн, які відчували на собі гострий брак високоосвіченого кадрового потенціалу, одразу взялося за справу створення сприятливого мікроклімату для новоприбулої української інтелігенції (зокрема, Чехословаччина) (Мицююк, 1942). Частина західноєвропейських країн флагманів розвитку освіти і науки в досліджуваній частині світу - не надто знепокоювалася питанням комфортного облаштування благодатних місць для українства, яке прибуло на чужоземні терени (Німеччина, Велика Британія Франція та ін. держави) (3aставний, 1991).

Прогресивні українські освітяни за кордоном, усвідомивши, яка велика кількість підростаючого покоління опинилася за межами рідної домівки, одразу перейшли до форсованого наступу боротьби 3 неграмотністю та малоосвітченістю. У пошуках джерелознавчої відповіді, що ж активізувало українських подвижників до рішучих просвітницько зорієнтованих дій на іноземній території, наведемо наступну тезу: "...ніде так дарма не розпорошується національна енергія в індивідуальній безпрограмовності, як поміж українцями" (Завдання української.., 1920, с. 8).

Закарбування у національній пам'яті інтелігентного українства ідейної пріоритетності педагогічної майстерності послугувало життєздатною рушійною силою на шляху налагодження освітньої справи в різнокультурних умовах іншомовного середовища.Доцільно підкреслити, що окремі представники професорсько-викладацького складу, яким пощастило побувати за кордоном 3 освітньою чи науково-дослідницькою метою, налагодили досить тісні професійні і частково дружні стосунки із знатною професурою того часу. Це послугувало своєрідною підвалиною для розбудови міцної будівлі україноцентрованої освіти на іноземній території.

Досить вагомим контраргументом інтелігентної української професури у відповідь на руйнівні соціокультурні вихори, які прокотилися військовими діями та радянським тоталітаризмом по європейських теренах, став високоповажний науково-педагогічний статус у високоосвічених колах світу. Так склалося історично, що Україна була житницею педагогічного новаторства і посідала досить вагоме місце в самому "серці" освітнього розвитку нашого континенту.

Тисячолітня боротьба українства за утвердження омріяних освітніх традицій, що відбувалася тривалий період на рідних теренах у наявних соціокультурних реаліях, не принесла бажаного полегшення тогочасному поколінню українців. Уникаючи надмірної авторської гіперболізації у змалюванні всієї поліколірності окреслених історичних перепитій, слід підкреслити, що феномен "еміграція" у практичному ключі ніколи не передбачав благодатну сприятливість соціокультурного розвитку, у тому числі й освітнього. I навіть глибокі та щирі суспільні бажання навчатися та навчати у єдиноначальному своєму обсязі не в змозі були б переструктуризувати іноземний лад на повноцінну національно-державну колиску.

Розглядаючи окреслену проблему з психологічно-особистісного кута, помітним чином вимальовується ряд проблем, які спочатку торкалися внутрішнього світу тих особистостей, котрі були достатньою мірою слабкими за духом. Таких представників соціуму спіткали системні депресії, песимістичні тематики нескінченних думок, що в окремих випадках породжували суїциди. Безу- мовно, що осіб зі стійкою життевою позицією теж збентежували сумні новини про депресивних співвітчизників, а тому надія налагодити дієву систему освіти в еміграційних умовах стала життєздатним началом не лише для правильного виховання, навчання, розвитку, але й, певним чином, і належної психологічної підтримки саме тієї частини українства, яка іiі гостро потребувала. Тому нагальна потреба розвивати освіту була не примхою зацікавлено-високоосвічених кіл у примноженні робочих місць, а соціокультурною необхідністю врятувати молоде покоління українських емігрантів від "самострати".

Досить важливо підкреслити ще один історичний факт, що українським освітянам-емігрантам випало нелегке завдання - налагодити роботу національної школи за кордоном, яку ще на рідних теренах "лихоманило" від денаціоналістичної політики діючих імперій. Тисячоліттям посилене різке скорочення кількості шкіл, масове закріпачення, жорсткий урядовий гніт - це основні ознаки тієї проімперської "лихоманки", що націлювалася на витіснення національного питання та викреслення ознак народності на проукраїнській освітній канві. Матеріали джерелознавчої бази засвідчують, що проросійська частина України дещо більше постраждала від імперського лихоліття, аніж західні регіони від політики Польщі та Австро-Угорщини (Списки вчителів, лекції...). Останню джерелознавчу закономірність, вочевидь, можна пояснити більш вищим рівнем національної культури наших західних сусідів, значний вплив на яку мав гуманістичний стрижень країн Західної Європи. У цій же фактажності виявляється парадокс проросійської історії, оскільки першопочатково зародження і розвиток православ'я передбачав утвердження найбільшою цінністю любов до ближнього.

Висновки та перспективи подальших досліджень. Підсумуємо, що високий показник чисельності українства за кордоном та низький рівень самоорганізованості емігрантів, які довільними хвилями торкалися іноземних 
кордонів різних держав світу, сумарним чином значно ускладнювали внітрішньоорганізаційні процеси організації української школи. Завдяки подвижницькій цілеспрямованості просвітницьких ініціатив удалося налагодити освітню справу у вітчизняних колах наших співвітчизників на перехресті еміграційних умов. Завдяки високому рівню цілеспрямованості та педагогічної майстерності досягнуто певних успіхів навіть у жорстких умовах еміграційних таборів, що засвідчено даними джерелознавчої фактажності. Перспективи подальших досліджень убачаємо в дослідженні педагогічних персоналій обраної епохи в міжнародному розрізі еміграційно-просвітницьких ініціатив.

\section{СПИСОК ЛІТЕРАТУРИ}

Баран, С. (1995). Українська еміграція між двома світовими війнами. Енциклопедія українознавства (Т. 2, с. 571-577). Київ.

Білас, I. (1994). Репресивнокаральна система в Україні. 19171953. Суспільно-політичний та історико-правовий аналіз (Кн. 1). Київ : Либідь - Військо України.

Завдання української студентської молоді в Чехословаччині. (1920). Український студент, 1, 3-8.

Заставний, Ф. Д. (1991). Українська діаспора (розселення українців у зарубіжних країнах). Львів : Світ.

Інструкція для внутрішнього життя Товариства б. вояків Армії УНР. Б. м. : Б. в., б. р.

Ковалів, П. (1953). Василь Сімович. Вінніпег : Вид-во УВАН.

Леник, В. (1990). Вчора, сьогодні, завтра. До історії українського інтернату в Мюнхені. Мюнхен : Рідна школа.

Мицюк, О. (1939). Доля украї- нської еміграції у протектораті Чехії та Моравії. Діло, 25 травня.

Наріжний, С. (1942). Українська еміграція. Культурна праця української еміграції між двома світовими війнами. Ч. 1. Прага.

Шевченко, Тарас. (2006). Світ правди засвітить Кобзар. Кобзар. 1840-1940. Черкаси : Брама-Україна.

Семчишин, М. (1993). Тисяча років української культури. Історичний огляд культурного процесу. Київ : АТ "Друга ріку".

Списки вчителів, лекції і окремих курсів, які читатимуть в таборах перебування наших козаків. ЦДАВО України, ф. 4465, оп.1, спр. 370, арк. 1-4.

Терлецький, М. (1995). На еміграції від 1919 до 1950. Еничиклопедія українознавства (T. 3). Київ.

Трощинський, В. (1994). Міжвоєнна українська еміграція в європі як історичне і соціальнополітичне явище. Київ : Інтел.

Українське еміграційне студентство в цифрах. (1922). Український студент, V, 73-76.

Фельштинский, Ю. К. (1991). К истории нашей закрытости. Москва : Терра.

\section{REFERENCES}

Baran, S. (1995). Ukrayinska emigraciya mizh dvoma svitovymy vijnamy. Encyklopediya ukrayinoznavstva (T. 2), s.571-577.

Bilas, I. (1994). Represyvnokaralna systema v Ukrayini. 19171953. Suspilno-politychnyj ta istoryko-pravovyj analiz (Kn. 1.). Kyiv : Lybid - Vijsko Ukrayiny.

Zavdannya ukrayinskoyi studentskoyi molodi V Chexoslovachchyni. (1920). Ukrayinskyj student, 1, 3-8.

Zastavnyj, F. D. (1991). Ukrayinska diaspora (rozselennya ukrayinciv u zarubizhnyx krayinax). Lviv : Svit.

Instrukciya dlya vnutrishnogo zhyttya Tovarystva b. voyakiv Armiyi UNR. B. m. : B. v., b. r. Kovaliv, P. (1953). Vasyl Simovych. Vinnipeg : Vyd-vo UVAN.

Lenyk, V. (1990). Vchora, sogodni, zavtra. Do istoriyi ukrayinskogo internatu v Myunxeni. Myunxen : Ridna shkola.

Mycyuk, O. (1939). Dolya ukrayinskoyi emigraciyi u protektorati Chexiyi ta Moraviyi. Dilo, 25 travnya.

Narizhnyj.

S. (1942).

Ukrayinska emigraciya. Kulturna pracya ukrayinskoyi emigraciyi mid dvoma svitovymy vijnamy. Praga : B.v.

Shevchenko, Taras. (2006). Svit pravdy zasvityt Kobzar. Kobzar. 1840-1940. Cherkasy : Brama-Ukrayina.

Semchyshyn, M. (1993). Tysyacha rokiv ukrayinskoyi kultury. Istorychnyj oglyad kulturnogo procesu. Kyiv : AT "Druga riku".

Spysky vchyteliv, lekciyi i okremyx kursiv, yaki chytatymut $\mathrm{v}$ taborax perebuvannya nashyx kozakiv. CzDAVO Ukrayiny, f. 4465, op.1, spr. 370, ark.-4.

Terleczkyj, M. (1995). Na emigraciyi vid 1919 do 1950. Encyklopediya ukrayinoznavstva (T. 3). Kyiv.

Troshhynskyj, V. (1994). Mizhvoyenna ukrayinska emigraciya $v$ yevropi yak istorychne i socialno-politychne yavyshhe. Kyiv : Intel.

Ukrayinske emigracijne studentstvo v cyfrax. (1922). Ukrayinskyj student, V. s. 73-76.

Felshtynskyj, Yu. (1991). K ystoryy nashej zakrutosty. Moskva : Terra.

Стаття надійшла 16.04.2020 p. 